HStud 22 (2008) 1-2, 43-62

DOI: 10.15566/HStud.22.2008.1-2.4

\title{
CULTURAL ALTERNATIVES, YOUTH AND GRASSROOTS RESISTANCE IN SOCIALIST HUNGARY - THE FOLK DANCE AND MUSIC REVIVAL
}

\author{
BALÁZS BALOGH - ÁGNES FÜLEMILE \\ Institute of Ethnology of the Hungarian Academy of Sciences, Budapest \\ Hungary
}

\begin{abstract}
The paper aims to look at those community-organizing phenomena that provided alternatives to officially supported, mandatory youth activities and played a vital role in the everyday life of young people in socialist Hungary in the 1970s and 80s. The urban folk dance and music revival, the so-called táncház (dance house) movement, is highlighted. The authors argue that the dance house as a subculture with its concept of "authenticity" was able to create common identity with the intrinsic notion of oppositional stance. Parallels are drawn between sports, rock music, literature and the dance house. The process of disintegration and folkloristic discovery of traditional peasant culture in Hungary and in Transylvania, communist peasant policy, and the connections between cities and villages are discussed alongside the phenomena of revival and issues of identity.
\end{abstract}

Keywords: communist peasant policy, socialism, disintegration, folklorism, folk music and dance revival, urban youth movement, authenticity, Transylvania, solidarity, rock music

Hungary has a uniquely wide spectrum of activities in the revival folk dance and music scene. The perception, reinterpretation and representation of peasant art by non-peasants have seen many waves since the first part of the 19th century. The rich variety of regional peasant traditions evolved gradually from late medieval and early modern antecedents, peaked in the 19th and early 20th centuries, and has been disintegrating over the course of the 20th century up to recent times. ${ }^{1}$ In Hungary state-of-art ethnography developed at this time, coinciding with the hey-day of folk art. The living phenomena of peasant culture in the field and the rich data of ethnographic recollection both served as sources of folklorism. ${ }^{2}$

One of the most recent waves of folkloristic discovery was the so-called "dance house" movement (táncház ${ }^{3}$ ), an urban grassroots youth revival movement that emerged in the 1970s and 80s in the period of late socialism.

Several prominent intellectuals writers, poets, and scholars had leading roles in the revival movement. Ethnomusicology and dance study provided a serious 
scholarly background and gathered together with the young amateurs an enormous amount of field material into archives, which was possible due to the longevity of peasant culture in some regions of the Carpathian basin. ${ }^{4}$

The movement reinvented the institution of the village dance house in urban settings and focused on the process of learning freely varied, improvisational, yet rule-bound dances for live musical accompaniment. Young people, who were searching for a "true," "authentic" tradition, started relearning the technique and the style of dance and music from the "last" remarkable personalities of peasant performers in the field within Hungary and among minority Hungarians in neighboring countries. In a way there is a unique continuity in the transmission of knowledge from the "last preservers" of traditional knowledge to the first generation of dance house musicians and dancers. As a result there is a rich repertoire and a very high standard of quality of dance and musical knowledge in the consecutive dance house generations.

Pilgrimages made to the "sources" revealed the narratives, unspoken until then, of Hungarian minority existence in the neighboring socialist countries for a subgroup of the young people. The movement, in addition to fostering pride in "national culture", was able to mediate a flexible, tolerant attitude toward other ethnicities through the interactions that took place in the field, in the dance-clubs, and in festivals.

In the period of milder political suppression of late reform socialism, the dance house established strong communities of young people with similar tastes, values, sets of identities and critical ideas deviating from the official view.

The fresh experience of improvisational dance that started as an amateur movement soon revolutionized the concepts of choreographed performances and created a new sensibility and politics of staged dance as well.

More than 35 years after its beginning, the revival is now a complex halfprofessionalized and institutionalized movement with several music bands, professional dance-ensembles, amateur groups, choreographic workshops, music schools, folk-clubs and summer-dance camps with arts and crafts activities within and outside Hungary.

One of the key components in the strength of the attraction of the dance house movement was the sense of belonging it gave to young people. This article discusses the ability of the dance house to create a deep sense of uniting community in the period of late socialism in the 1970s and 1980s in Hungary. We argue that the dance house as a subculture with its interpretation of tradition was able to create common identity and worldview with an intrinsic notion of an oppositional stance to the prevailing political doctrine. The dance house, together with rock-music, self-organized sports, literary circles, film clubs, and amateur theatres, was part of the everyday recreational activities of urban young people and the channels for the expression of freed emotions and critical opinions. These circles 
of activities provided alternatives to the official, centrally organized, communist youth movement's mandatory ideology. To understand the context of the birth of the revival movement, the antecedents of the 1950s and 1960s should be briefly elucidated.

From the end of World War II to the change of regime in 1989-90 the rural population in Hungary underwent staggering social changes. Although World War II was a cataclysmic upheaval, it did not bring about a direct change in social structure, mentality or culture. Rather, with the agrarian reform of 1946 a "re-peasantization" phenomenon occurred. There are quite a few examples of communities, the last small enclaves, where the abandonment of some aspects of peasant culture took place only between the 1950s and 1980s. After the lean period following the war came the harsh dictatorship of the fifties, with the oppression of the well-to-do peasantry. The political change of 1948, with the communist takeover of power, immediately began the introduction of the Soviet-type, intolerant anti-peasant policy. Persecution, kulak-lists, imprisonment, deportation to labor camps, political trials and coercive requisitions marked the period.

Until World War II, many forms of organizations, clubs, and associations operated even in the smallest villages, which strengthened the communities' awareness of belonging, from reading circles to the fire brigade, brass-orchestras, artisan circles, and church youth organizations. These communities organized from the ground up were completely smashed and banned by the post-war communist dictatorship.

The ruling ideology labeled peasants (more than half of the population) as a reactionary vestige of feudalist clericalism and capitalism, a class targeted for elimination. Communist demagogy sharpened conflicts between towns and villages. Newspapers, schoolbooks, products of the new socialist film industry, and ten-minute newsreels (a compulsory must before movie screenings, even up to the 1980s) aimed to illustrate the bluntness and shrewdness of those who insisted on outdated traditions, the "haunting shadows of the past", in comparison with the enlightened modern socialist heroes and heroines of the new age. Young boys and girls of agrarian proletarian background who were taught in the newly set up People's Colleges (Népi Kollégium) ${ }^{6}$ with the aim of transforming them to loyal cadres of the regime were supported and in fact turned against their past. The political and ideological stress and the burden of devaluation and deprivation of self-pride urged peasant communities to step out of their traditional cultural expressions, which was decoded by this hostile environment as a badge of "kulak-ness."

On the other hand, a Janus-faced rhetoric began to exploit a falsified vision of "folk culture" within the realm of socialist realist "art." Gigantic frescoes and monumental statues in public spaces and staged choreographies of state folk ensembles all advocated the myth of friendship between the "happy" peasants and workers. ${ }^{7}$ 
Like other aspects of culture, dancing as a stage-performance was also an ideologically controlled activity. In addition to the Hungarian State Folk Ensemble (established in 1951) some ministries (for example the Ministry of Interior, the most feared organ of the 1950s) and the trade unions financed the management of dance groups. ${ }^{8}$ Dance on stage was accompanied by symphonic orchestras and big choirs. Choreography was characterized by highly stylized genre scenes of folk customs: subject or "character" dances using folk dance steps without accurate knowledge of whole sequences of improvised traditional dance. ${ }^{9}$ Following the Soviet model, the demonstration of folk dance at public political and cultural events, official festivities, commemorations, and Labor Day processions mediated the aspired triumphal message: "the peasantry belong to us, they are loyal to us." State and party apparatchiks were responsible for keeping an eye on the artistic activities of these groups and traveled with them to festivals to control and report the behavior of their members (even as late as the 1980s). Instead of bringing folk art closer to people, the engineered folklore-show presentations, a tool in the production of ideology, taught many to abhor and distance themselves from it.

For those few local peasant communities that continued to insist on their traditional outlook and customs, the decisive moment towards assimilation was the period of wide-scale and violent collectivization in 1959-1961. Soviet-style collectivization was consistently carried out after the crushed 1956 anti-Soviet revolution, bringing an end to traditional peasant existence. The land, which was the basis for the sustenance of family households around which values and institutions were organized, was pulled out from under the feet of the peasantry. An avalanche of changes ensued. It was following forced collectivization that the hitherto traditional culture of the villages dissolved with extraordinary rapidity. Individual farming, which had provided the basis for the village way of life, ceased, so-called "cube houses" appeared everywhere in place of the old long peasant houses, and villagers who still wore costumes dropped their traditional attire. The profound changes could be listed at length, right up to the overturning of the system of norms and the hierarchy of prestige of the community. ${ }^{10}$

Between 1948 and 1965 two-thirds of society was socially mobilized. Villagers were forced to work in the cooperatives and people became commuters in big industrial estates. In fact it was a long-awaited and needed mobilization process after the hierarchic semi-feudal social system of the pre-World War II period. It is also true that for many people of poor peasant or worker origin the 1960s was the first period ever in their lives during which there was adequate food to soothe their hunger. But the rhythm of the social change was too fast-paced, too dynamic and above all engineered from above for the initiation of an absolute regime which smashed any seeds of real democratization. The high rate of intra- and intergenerational mobility had all the negative side-effects of forced rapid mobiliza- 
tion: suicides, alcoholism, negative birth rate, split families, divorces, social trends in which Hungary is regrettably among the forerunners in Europe.

From around 1963-64 a more pragmatic, milder form of economic planning was introduced. Instead of exclusive concentration on heavy industry, light industry started to be developed as well. Socialist consumerism evolved shops and warehouses were established alongside the construction of big housing estates in which the obtainment of an apartment entailed prestige and a rise in living standards. Public transportation was improved. The increase in the number of active workers included the entrance of one-million women into the workforce. An improved network of day-nurseries, schools and health service were needed. The idea of leisure was born for large masses with the network of vacation houses for workers. Work collectives and school classes began to travel on excursions or visit theatre performances. Magazines and the start of television broadcasting (in 1957, although possession of a television set only became widespread in the mid-1960s) provided strong role models of speakers and actresses. All this made the urban model popular and inviting for the young generations of the rural countryside. Young people in the 1960s working and studying in the urban-industrial centers who brought mates from outside the traditional marriage circle began to find the divergent cultural expressions increasingly uncomfortable. These forces of modernization and urbanization sped up the process of the disintegration of peasant culture. Folk dance in its original social environment started to fade away together with the traditional family and community occasions.

There is a long cultural and social history behind the phenomenon according to which the acceptability, prestige and place in collective consciousness of peasant culture is characterized by a sort of duality. Even though interest in folk culture in Hungary goes back more than 200 years, and even though it has become one of the cornerstones of modern national culture, the attitude of society towards it is nevertheless full of contradictions. Practices of symbolization and expropriation produced a rich array of connotations (real or imaginary qualities) attached to the concept of folk as attributes. In addition to enthusiastic acceptance, negative emotions of a similar intensity can be observed in the rejection. In Hungary there is a long history of the discourse dichotomizing dipolar values such as rural versus urban, East versus West, and national versus international. ${ }^{11}$ Fixated stereotypes about both sides often prevented the possibility of understanding and increased the manipulative exploitation, accusative attribution or expropriation of certain qualities and values. These often politicized discourses of intellectuals went on without the peasants, the carriers of the culture under discussion, being aware of it at all.

Children of the 1960s were brought up in the spirit of an ambiguous attitude toward folk culture. Compulsory elementary music education based on the praised Kodály-model introduced folk songs to the curriculum, but it was felt as an obli- 
gation by many. The radio broadcast arranged orchestrated or choral compositions based on folk tunes, a musical genre that never gained popularity among the young people. School books showed images and stories on peasants, the rich peasants appearing with negative badges and the agrarian proletarians with positive badges as the ideologically correct segment of rural society. But all this was not enough and in fact did not aim to dispel the general pejorative stereotypes of everyday communication and public discourse about the peasant village. The negative stereotypes were definitely milder than the "kulak-slogans" of the 1950s anti-peasant propaganda. But this tamed image was still sharply sarcastic. Anyone coming from the countryside, i.e., from outside Budapest, was teased with labels, such as "mucsai paraszt" (peasant from Mucsa), a mocking epithet meaning hopelessly stupid and unprogressive. ${ }^{12}$ That children willingly mocked each other with such expressions represented the public thinking of the time. Pedagogues and nurses often expressed their dislike of "old-fashioned" everyday customs and practices to families of peasant origin in a patronizing manner. One of the urban traffic centers from where the long-distance buses started was nicknamed "peasant-distributor" (parasztelosztó) for decades. This hierarchy, the over-exaggerated superiority of Budapest, often caused wounds of inferiority complexes. ${ }^{13}$

Urban youth of the 1970s may have childhood nostalgia for the world of the grandparents they visited in the villages during summer vacations. But for most of their childhoods they were brought up in a general climate that lacked appreciation for and looked down on the countryside. The framework of most of the daily activities outside of the family were the school, the communist youth-organizations (from first elementary class), choir-singing (with the dominance of the songs of the international communist movement), and the state-sponsored sport and summer camps. From the centrally defined yearly topics of pioneer activities to stamp-collecting and pen-pal connections with children of the socialist camp, the whole machinery propagated the triumph and ethical superiority of socialist modernization, urbanization and internationalism.

Sport life was also organized on the Soviet model, with the two pillars of club sports and mass sports movement. In the sport bureaucracy there were several jobs for the party nomenclature. The display of healthy bodies of young athletes symbolized the strength of the People's Democracy over the decadent West. The socialist media helped create a messianic atmosphere. Sports provided almost the only opportunity for a decent carrier and travel abroad for those who came from politically and socially declassee peasant and middle class families. From the fifties sport events offered the only opportunity for fans to declare their national feelings openly. The party leadership was well aware of this and tried to exploit it. In order to gain popular support for the Kádár regime sportsmen were among the first to be rehabilitated after the 1956 revolution. Nevertheless, until the regime change in 1990 sport events provided almost the only occasion when the Hungar- 
ian flag could be used without the Soviet red flag that symbolized the power of the workers. $^{14}$

From the early 1970s some musicians (first the Sebö band and soon after the Muzsikás,Virágvölgyi, Jánosi, Vuicich, Téka, Kalamajka, etc.) and amateur dance groups, most importantly Sándor Tímár's Bartók Folk Dance Ensemble, turned toward the rediscovery of live folk dance and music. ${ }^{15}$ The dance house was at once based on the collection, examination and processing of the now fading folk culture, as well as the demand for the experience of a strong emotional sense of community. The doors of the first clubs were opened for and attracted wider urban audience, students, intellectuals, and white and blue-collar workers who had no family tradition of dance and music on which to rely and had to learn everything from the very basics. That is why dance instruction became an indispensable part of the revival of the dance house in order to share the "knowledge" with anyone interested. Soon clubs formed around music bands and dance instructors (who were members of the best amateur ensembles) started to mushroom in Budapest and in provincial cities (Székesfehérvár, Szeged, Pécs, Jászberény, etc.). György Martin, Hungary's foremost academic dance scholar, helped shape and direct the movement with his advice, field expertise, and network of connections right from the very beginning. As the movement advanced and more and more regional traditions were highlighted, the knowledge of the musicians and dancers deepened, and they became familiar with many styles of dance in their complete sequences of dance suites, from men's dances to slow and faster couple dances from singular regions and localities. Behind dance and music a larger context of a complex integrative culture was discovered and appreciated.

There are some important antecedents to the movement. ${ }^{16}$ Among the folk ensembles, the amateur groups of the trade unions were less strictly controlled than the state folk ensembles. In the 1960s some important choreographic experiments started to be carried out in these workshops, which served as a hotbed of the dance house movement. The other immediate antecedent was a televised folk song talent show entitled "Röpülj páva" ("Fly Peacock") in 1969-1970. ${ }^{17}$ The only TV channel of the country was the single medium and enjoyed enormous popularity. The show accelerated the establishment of several Fly Peacock circles ("Pávakör") in many localities of the country. Parallel to the dance house, a movement of the so-called tradition-keeping ensembles emerged in the 1970s. The contests of the "tradition keeping ensembles" brought singers, choirs and zither bands of peasant villages, and middle aged women and men garbed in traditional or quasi-traditional costumes of their villages to the spotlight, singing the folk song repertoire of their communities. As a result people began to attribute value to their recently abandoned local folk culture or to a lesser extent to the residues of the yet vibrant elements of that culture. The Fly Peacock movement started to prove that folk songs can stand on their own, without being transformed into orchestrated, 
semi-classical compositions. The idea of Béla Bartók and Zoltán Kodály, Hungary's foremost composers, concerning music education based on folk music as the means through which to create a Hungarian "musical mother-tongue" ("only from pure spring") offered legitimacy and a sort of "brand name" for the movement. That the Fly Peacock repertoire consisted mostly of the so-called "new style" songs performed by peasant women's choirs, a sound that became boring after a while for the younger generations, is another question. When the more archaic musical heritage of Transylvania was discovered by the dance house musicians it sounded very different from the Fly Peacock movement's new-style repertoire. It sounded like a revelation, a voice of an unknown archaic sunken world. Although the dance house built on the popularity of the folk song established by the Fly Peacock movement, it immediately contrasted the freshly discovered archaic sound as "authentic" against the more "vulgar" popular sound of the Fly Peacock style.

There were international trends as well, which served as wider context. In the late 1960s and early 1970s a new interest in folk music and dance developed in many countries. ${ }^{18}$ Scholarly studies about revival movements, whether they concentrate on the USA or Europe, underline similar motifs: the new aesthetic; the emphasis on active, creative participation; ${ }^{19}$ the movement's conception of itself as a legitimate form of continuity of an "authentic tradition" and a sense of community.

As happens in many nostalgic revival movements, the turn to the past primarily valued and sought what was possibly the most archaic phenomena. But this archaism had to have a specific feature, notably it had to be a living phenomenon that could be experienced in the present and through personal involvement. It had to be a kind of "living past," which at the moment of discovery was not a reconstructed display-event, but a functional, 'in situ' integral performance of dance, music and community customs.

Although led (remarkably) by intellectuals, the movement was "amateur" in that the admiration and the interest turned not (or not only) towards single fragments of a one-time complex system of knowledge (fragments that could be interpreted only by experts trained for scholarly reconstruction), but rather towards the complexity of culture itself. Young people searched for an integral entity of community being in which the local community did not figure merely as a passive consumer of cultural goods and practices coming as a service from the outside, but rather maintained the ability to create and periodically reproduce culture of its own in accordance with its traditional system of knowledge, practices and estheticism. 'Traditional' in this aspect meant that the transmission of knowledge was through personal, face-to-face communication between consecutive generations. 
As a consequence of the above mentioned motivations, the dance house movement had a specific ability to establish a wide network of small circles of peoples who behaved not as part of a passive audience but from time to time actively participated in the re-creation of a cultural product. One of the strengths and successes of the dance house lay in the improvisational character of dancing. The face-to-face transmission of knowledge, the technique of playing music, the rules of building up an improvisational performance, the sensitive interaction between the dancers and the musicians or among the dancers is very similar to the traditional circumstances of dance in the original context. While improvised dancing requires skill and effort to learn, it can be done on very different personal level of knowledge, no one is excluded, and first and foremost participation is voluntary. On the other hand the process of the active creation of dance gives exceptional joy in comparison with the keenly memorized mechanical processes of fixed choreography.

These grassroots circles of voluntary groups of sociable young people sharing similar ideas, tastes and world-views provided a real alternative in the period of socialism, when participation in the communist youth movement, school events, commemorations and political demonstrations were all mandated and ideologically manipulated. It was a real shift from the disfavored compulsory passive presence to a voluntary, emotionally supported active participation, which also created a strong feeling of commonality and solidarity.

These circles have wide and loose, flexible boundaries, so in the strict sociological sense they cannot be defined as communities. They are "instant communities" with a temporary and spontaneous composition of people who show up randomly for a particular event at a particular place. This flexibility results a "loosely-knit association of informal communities." ${ }^{20}$ But the feeling of community can be easily reproduced at any time by the uniting act of singing and dancing together. The awareness of belonging is coded by the participating persons, even by those who meet for the first times in their lives, with the meaning of you are one of us, we have similar taste, we think in the same way and understand each other.

Given the intensity of emotional identification, the dance house has influenced the shaping of identity, although it should be emphasized that at least within Hungary proper this does not coincide or does not entirely coincide with ethnic lines. (The case was different among minority Hungarian communities outside Hungary because of the differing context and dynamics of majority-minority relationships.) Ethnicity played a role, though not a primary role, in the vital appeal of the movement. From the very beginning the dance house has had a general appreciation for any ethnic traditions that represented a similarly "authentic," "original" sound. ${ }^{21}$ Béla Halmos, the fiddler of the Sebö Ensemble, the very first band of the dance house movement which had a decisive role in shaping and disseminating the new attitude towards folk traditions, writes the following: 
From the very beginning, the dance house movement has treated the folk cultures of Hungary's non-Magyar ethnic groups, and indeed, of every nation, as treasures of coequal value (and, in this sense, followed a principle and a practice that anticipated the 'Common European House' idea by some twenty years). ${ }^{22}$

The archetype of the creative peasant village with unspoiled, integrative culture and the dream of the site where the clock of civilization ticks more slowly was sought and in fact found in the Transylvanian community of Sic (Szék). While fragments of traditional culture along with the last good musicians and dancers were found in quite a few regions of Hungary proper, none of these localities could provide the complexity that Szék and afterwards other Transylvanian communities offered. In fact the localities in Hungary proper largely remained research fields of dance experts such as György Martin and choreographers such as Sándor Tímár. But the wider interest turned primarily towards Transylvania as a depository of traditions, a momentum that shaped and strengthened the identity of the dance house.

Dance house fans started to travel to the regions of Transylvania inhabited by Hungarian speakers and hunt for events with traditional music and dance, balls, dance houses, weddings, and farewell parties for soldiers. At this point the traditional dance and music subsisting in Transylvania converged in its encounter with the urban revival movement, both in Budapest and in the field, and the bringing of "informants" to the Budapest dance clubs and the travel of dance house participants to the field. Personal contacts, narratives of minority grievances, the experience of the hardships and anomalies of life in Ceausescu's Romania, the warm emotional welcome by the Transylvanian Hungarians, who felt long-forgotten and neglected by the government of the "mother country," all opened the eyes of an entire generation of young dance house fans, who otherwise hardly heard anything about Hungarians outside Hungary. A student could easily finish schooling without ever hearing about the Székelys (for example), the largest regional Hungarian minority group consisting of some one-million people. Novels of Transylvanian writers of the interwar periods were censored as dangerous works and were closed into prohibited library stocks in Hungary. In the name of fraternalism among the peoples of the socialist camp, discussion of national conflicts was stifled, leaving minorities at the mercy of the majority. Mention of the pre-1920 formerly Hungarian territories was immediately labeled as imperialist revisionism and chauvinism. On the other side of the border memories and repositories of the Hungarian past of large regions of Czechoslovakia, Romania or Yugoslavia were muted, closed away, left in decay or systematically destroyed. Given the need to maintain the (illusion of) the common consensus of Socialist Friendship (which in reality meant distrust, severe police control, and the imprisonment of progressive minority intellectuals), the grassroots discovery of 
minority Hungarians and their folk culture through personal contacts became highly inconvenient for the regimes on both sides of the border.

With the growing interest in the Hungarian communities the Romanian government started to make border crossing more difficult and prohibited staying in the private homes of acquaintances who were not close relatives. The decree to report oneself immediately with the police when spending a night in Romania further encumbered this highly controlled ethnic-tourism. To travel to Transylvania was a risky adventure, especially in the last decade of the Ceaușescu regime. Standing in the line at the border for some twenty hours, being body-searched and sent back to the end of the line because of an innocent children's story book or Hungarian weekly magazine and the feeling that the police could stop and interrogate you at any time within the country gave the Transylvanian visits a notion of traveling to the land of an Orwellian totalitarian irrationality, and in fact it was a liberating feeling to arrive home safe to Hungary to relative freedom and economic prosperity.

A specific symbolization and sacralization process had been taking place. The improvisational dance, moving and breathing together and responding sensitively to the movement of other bodies, and interacting with live music gives exceptional joy incomparable to any other form of recreational sports. Dancing the dances of the "marveled" Transylvanian communities and dancing together with the Transylvanian villagers created powerful emotions of solidarity. In stage performances the complex "mimicry" of dressing in local garb, holding one's body and behaving as if one were one of the locals, singing local songs and listening to local music created an exceptional opportunity to become one with the bearers of traditional culture. That the performance-like manifestation of the traditions of suppressed minority Hungarians in the neighboring countries on stage was perceived as a strong statement against the neglectful attitude of the communist leadership toward Hungarian minority issues is another matter.

In this context the new authentic sound folklore performance gained an intense manifest meaning. The archaic Transylvanian regional musical styles have been over-represented and the most popular "pop-songs" or "protest-songs" of the dance house, such as the "Wind blows cold" or "It is not like as it was in the past, it is not the same sun which shines," were also from Transylvania. In this respect "authenticity" started to mean the "revealing of the hidden truth." The new-wave (authentic-sound) revival music and dance as an act of "protest" in the making and the demonstrative character of the stage performances has become a new channel for the expression of collective memory and identity.

The dance house spread not only among Hungarian minorities of Romania, Yugoslavia and Czechoslovakia, but also reached West European, North American and Australian Hungarian emigrant communities as a trans-political-border national phenomenon. It created an opportunity for a young generation to develop 
connections among distant groups of the territorially fragmented Hungarian people in a period when there was much distrust in the older generations of Western émigré communities toward anything that came out of Kádár's socialist Hungary. The dance house was a force that was able to unite young people in the belief that there existed a cultural nation that transcended political borders. With the growing popularity of the dance house movement, its influence acquired international dimensions. Dance enthusiasts from Sweden to Holland to the USA to Japan started to visit Hungary and Transylvania regularly. This Western folklore-tourism created the first opportunity for the Hungarian youth of the late 1970s and 80s to build personal friendships reaching beyond the Iron Curtain and awake the interest of people in the West in Hungarian minority questions.

In the 1970s that sharp national line of "sinful rock music pouring in from the West" appeared, which also offered the experience of community solidarity and which opposed the ideology of the internationalist socialist regime, at first subtly, then ever more openly. The regime did all it could to stop it: it censored song lyrics, denied certain bands the right to release records, banned concert performances in Budapest, etc. The creator of the culture-policy guidelines, later infamous as the "three T's" (named after the Hungarian words for supported, tolerated and banned), was György Aczél. The period of cultural politics bearing his name lasted from the mid-1960s until the early to mid-1980s, thus coinciding with the successes of the Kádár regime. At the same time, not even he knew what to do about a phenomenon within the cultural public's stratification in Hungary, whereby in the late 1970s and early 1980s the various anti-regime underground rock and punk bands broke on the level of subculture with the previous allegorical-metaphorical mode of speech. ${ }^{23}$ One of the most sharply delineable subcultures of this period was the group Beatrice, which was prohibited to make records. Its audience expressed its solidarity by wearing red and white polka dot kerchiefs (babos kendö) around their necks. Its Budapest fans gathered in the underground passage at Batthyány Square, directly opposite the Hungarian Parliament on the other bank of the Danube, where the police regularly rounded them up and checked their papers precisely on the basis of their easily recognizable kerchiefs. At Beatrice concerts the group regularly performed a block of folk songs set to rock music as well.

How and where rock music instinctively connected to the world of folk music is a topic deserving separate introduction. At that time both rock music and the dance house movement were a thorn in the regime's side. In the rock opera Stephen the King (István a király, 1982), an enormously influential musical work of the period preceding the change of regime, these threads came together in an obvious manner. ${ }^{24}$ The drama is about the conflict between two worlds, that of tradition and modernization, and possible directions of national destiny. The pagans opposing the Christian authorities sing to music built largely on folk elements and 
accompanied by folk instruments, bagpipes and fiddles. All at once on stage the icons of the dance house movement and rock music were singing together. Leading folk singer Márta Sebestyén with the Muzsikás band and many other folk musicians with a large group of folk dancers embodied the pagan camp, together with iconic vocalists of underground rock music. Feró Nagy (of the Beatrice group), Gyula Vikidál (of the P. Mobil group) and Gyula Deák "Bill”" (of the Hobo Blues Band) represented the pagan leaders rebelling to preserve tradition and against defeat by the Christian forces. At the end of the open air musical thousands in the enthusiastic audience were singing the Hungarian National Anthem, which was incorporated into the music of the finale, together with the performers. The time of Saint Stephen, Hungary's first Christian ruler, obviously symbolized an unbroken unity comprising all the people of the historic country prior its fragmentation. It is with good reason that Hungarian pop and rock music, and first and foremost "Stephen the King," became immensely popular among minority Hungarians outside Hungary in the 1980s and 90s.

However, it is also worth noting the divergent paths the two musical trends have traveled from the moment of the change of regime to the present day with regard to the expression of a community world of feeling. While folk music ensembles and the dance house movement in general cannot be accused of having given space to extreme views, such a feature was characteristic of the "national rock" current of rock music. In the life of rock music, by singing lyrics proclaiming extremist ideals bands often gather around themselves an audience (in fact rather sparse) that is open to this mode of speech. One could also say that the dance house movement derives its emotional experience of community from a reinterpreted 'tradition' for which the demand is unbroken, and under socialism it was precisely because of its tradition-preserving character, difficult to harmonize with internationalism, that it vexed the regime. For that reason, after the change of regime the movement was not emptied, rather its social background remained. Rock music as a genre was squeezed to the background by the more recent currents of light music, and opposition to the regime lost its relevance following the change of regime, so the background that fed the communal emotional experience was weakened and its mass base ceased to exist. With the marginalization of the genre a portion of these bands tried to recruit an audience along some sort of ideology, which in the case of bands playing "national rock music" inevitably led to distortions manifesting themselves in an overemphasis of national elements, often in dissonant outward forms. Thus, the dance house movement has preserved its societal support, independent of ideological-political changes, across a well-defined though broad circle of society.

Literature also merits mention here, and specifically the role of poetry. It was during the period of the rise of the dance house movement in the 1970s and 80s that one could speak for the last time of a markedly populist profile in Hungarian 
poetry, which bore the names (first and foremost) of Gyula Illyés, István Sinka, László Nagy, Ferenc Juhász and Sándor Csoóri. At the beginning of the dance house movement the folk-inspired scoring of poems with folk instrumentation was frequent, primarily in adaptations by the Sebö Ensemble. The bulk of the participants in the dance house at the same time also belonged to the readers' camp of the "populist poets." The constant guests of the dance house clubs were poets and writers whose readings regularly enhanced the evenings. In his poem written about Muzsikás, one of the definitive music ensembles of the dance house movement, Sándor Csoóri (whose son was a member of the band) called the group "brave lads facing death with copper axes," which aptly expresses the strength of tradition, the resolve in opposing the regime, and at the same time its hopelessness. László Nagy dedicated his poem Táncbéli táncszók (Dance-verses ${ }^{25}$ ) to the Bartók Folk Dance Ensemble, and the group performed a dance on stage to the rhythm of a loud recitation of the verse. László Nagy's text is reminiscent of the condensed forceful expression of the dance-verse genre of folk poetry, and the rhythm of the text was in fact shaped to the exiting asymmetric rhythm of dance music from the Gyimes valley in Transylvania. The poem is the rebellious voice of a pure generation that deserves ethical triumph over the corrupted world and whose only weapon is tradition: "Nem vagyok jó, nem vagyok jó senkinek Rám ugatnak égiek és földiek... Most rúgjon a sarkad szikrát Égesd el a világ piszkát... Mert mibennünk zeng a lélek, Minket illet ez az élet!..." (Nobody needs me, nobody needs me, all earthly and heavenly forces bark at me...your dancing heels ignite sparkle, burn the rubbish of the world...because the soul sounds in us, we deserve the life).

Beginning with the period of the change of regime, poetry has become marginalized, and as they usually joke in Pest: "only poets read on another's poems now." According to a resigned president of the Hungarian Writers' Union, the poet József Tornai, the utter marginalization of lyric poetry is connected to the change of regime and the collapse of communism:

I no longer believe that there will again come that time when a poem by Gyula Illyés or Feri Juhász could rouse the entire country. Today it is inconceivable that a Hungarian poem or a good volume would mobilize even the complete scale of the entire Hungarian linguistic territory. During the harsh, total dictatorships the true word and its most noble outlet, poetry, were appreciated. So shall we create a dictatorship for the sake of poetry? Nobody seriously wants this. Today it is the TV stars and reality shows that interest people here, as in the civilized world. ${ }^{26}$

It must be mentioned that in addition to the phenomena discussed above, there were also alternative theater and film clubs, primarily amateur, that struck a chord for the most part among members of the young intellectual university community, 
but these could not address wide masses of people in the same way that sports, music or poetry could. (In Poland, on the other hand, alternative theaters enjoyed a popularity and social weight comparable to the Hungarian dance house movement.)

Looking back on this era as a period in our own lives, we can declare without the slightest doubt that sports (first and foremost soccer), rock music, literature and the dance house movement were the most important community-organizing forces in the everyday life of the late 1970s and early 80s. Each of these areas of community-organizing forces supported and reinforced the others. In our generation and in our circle of friends it was completely natural for someone to be a fan of the Ferencvárosi Torna Club, take the national flag to international matches, play football with friends in an amateur championship, attend P. Mobil and Beatrice concerts, subscribe to the literary journals Élet és Irodalom, Mozgó Világ and Tiszatáj, purchase the annually published poetry anthology Szép Versek, travel to Transylvania, frequently visit the dance house, and listen at home to the latest folk music cassettes of the Muzsikás Ensemble and Márta Sebestyén. Day-to-day life was organized around these cultural alternatives, and we might even say that (apart from our romances) this occupied all of our free time.

It is also important to see that among the community-organizing forces detailed above, the dance house movement succeeded the most in maintaining its mass base. The marginalization of rock music, poetry and the soccer has been mentioned. For unlike success in sports, which depends on talent and especially money, poetry that opposes the regime by speaking the truth between the lines, or rebellious rock music, the dance house movement has been constantly able to show value in and of itself.

Nonetheless, political parties attempted to appropriate the dance house after the 1990s democratization. The dance house resisted and did not become the terrain of political demonstrations because this was not its primary meaning or content. The original content of creative art-activity and the complex enjoyment of dance, music and singing as entertainment within a friendly circle of people in which a feeling of community and solidarity can thrive remained the primary intent. $^{27}$

Notes

1 In large parts of Western Europe, where an earlier, more integrative embourgeoisement and a smoother transition from rural to urban had occurred in the early modern period, the culture of common people was not so strongly independent from the elite culture and general influences of fashion as was the case in East-Central Europe. In Hungary there was a deep social gap between classes, and although there were certain opportunities for social interactions, social mobility and trickle-down effects, on the whole the culture of Hungary's rural population started 
to become urbanized later, and it remained much more autonomously "peasant-oriented" and "peasant-flavored" than in the West. Thus, the most flourishing period of regional peasant culture was the 19th and the first part of the 20th century. (See among others: Hofer, Tamás: Peasant Culture and Urban Culture in the Period of Modernization: Delineation of a Problem Area Based on Data from Hungary, In: I. P. Winner - Th. G. Winner (eds.): The Peasant and the City in Eastern Europe. Interpenetrating Structures (Cambridge, MA, Schenkman Publishing Company, Inc. 1984), 111-129.)

Compared to the central part of the areas of the Carpathian Basin inhabited by Hungarian speakers, the peripheral territories of one-time historic Hungary that were handed over to the neighboring countries after the dissolution of the Austro-Hungarian Monarchy in 1920 often preserved an even more archaic state of rural culture. For example in several communities of Transylvania elements of traditional culture including music and dance were still preserved and practiced in the 1970s and 80s.

2 Folklorism in this context means a conscious fabrication of value, which is a result of the interests of other social groups: aristocrats, the elite, artists, intellectuals, the urban middle class and scholars on peasant culture. In search of the "authentic," certain elements of an "integrative" culture were elevated out of their original context, special values were attributed to them, and they were reapplied, "inserted," reinterpreted, and often distorted to achieve new meanings.

The definition of folklorism has awakened vivid scholarly interest. A useful summary concerning the ongoing discourse among various schools of European and American scholars can be read in Guntis Šmidchens: "Folklorism Revisited", Journal of Folklore Research 36(1) (Jan. - Apr. 1999): 51-70. In the study of Hungarian folklore Vilmos Voigt has extensively analyzed folklorism phenomena. See: Voigt Vilmos: A folklorizmusról. Néprajz egyetemi hallgatóknak 9 (Debrecen, 1990), in English Vilmos Voigt: "The Concept of Today's Folklore as We See It from Budapest, Hungary, Europe", Journal of Folklore Research 21(2/3), Culture, Tradition, Identity Conference, March 26-28, 1984 (May-Dec. 1984), 165-175.

3 The term táncház comes from the Hungarian community of Szék (Sic, Transylvanian Heath, Romania). It refers to the weekly organized dance occasion of the unmarried youth in the first room of a rented private house to the music of a hired local music band. The term and the institution, together with the dance repertoire of this community, were borrowed by the organizers of first folk dance clubs in Budapest from 1972. The anachronistically late traditionalism of this Transylvanian community was a revelation, a kind of time travel to the past. Szék has become the focus of folk pilgrimage since then. See: György Martin: "Discovering Szék", Hungarian Heritage 2(1-2): 31-40 (2001).

4 Ferenc Sebő, the decisive figure of the first dance house band and club (Kassák), mentions in an article that "the club movements of the 1970s emerged against a background of 150,000 collected and transcribed tunes, with much research and practical experience" Ferenc Sebö: "The Revival Movements and the Dancehouse in Hungary." European Centre for Traditional Culture (ECTC) Bulletin IV. Budapest 1998. 34-38. Since Béla Vikár, who recorded folk songs using a phonograph for the first time in Europe in the 1890s, several Hungarian musicologists (including Béla Bartók, Zoltán Kodály, László Lajtha, Pál Péter Domokos, János Jagamas, Benjamin Rajeczky, Pál Járdányi, Lajos Vargyas and others) have collected folk tunes and instrumental music systematically and in accordance with high methodological standards, also providing descriptive analysis, scientific classification, and comparative investigation of historical and stylistic strata. The editorial board of the Magyar Népzene Tára (Complete Edition of Hungarian Folk Music) was established in 1948 under the leadership of Kodály. In 1953 the team was officially declared to be the Folk Music Research Group of the Hungarian Academy of Sciences. It was headed by Kodály until his death in 1967. The archaic 
folk music of Transylvania, including the richly ornamented polyphonic instrumental music, had been discovered by scholars already in the 1940s and 50s (Sânmartin (Szépkenyerüszentmárton), Chidea (Kide), Sic, Crișeni (Kőrispatak), preceding the dance house movement.

5 The authors of this article, who are now senior research fellows at the Institute of Ethnology of the Hungarian Academy of Sciences, have personal memories as one-time active participants in the dance house and audience members at underground rock-concerts. Ágnes Fülemile started to visit the Budapest dance houses from the mid-1970s. She was a member of the Bartók Ensemble, the leading dance group of the dance house, from 1978. Balázs Balogh has a degree in literature and has published poetry since the age of 14 . He was a "serious" soccer and rock-music fan, who sang in an amateur rock-band and continues playing soccer in a team of one-time university fellows in a competition which has been going on since the 1980s. A similar personal encounter of the time can be read from the angle of a British anthropologist Chris Hann, who did years of fieldwork in Hungary in the 1970s and 80s and remembers experiencing rock and folk music and sport through personal involvement in friendly circles of young Hungarians. Chris Hann: "Memory Tracks: State, Nation and Everyday Life in 1970s Budapest," Berliner Osteuropa-Info 23: 17-23.

6 NÉKOSZ abbreviation for National Alliance of People's Colleges.

7 Giurchescu says about the cultural products of the period, "sophisticated performances, staged according to the Soviet model, were meant to symbolize through good technique, beautiful appearances, homogeneity, colorful costumes, and decoration, etc., etc. the achievement of the socialist policy, the happy life of the youth in the Communist countries, etc." Anna Giurchescu: "Power and the Dance Symbol and its Socio-Political Use (Keynote paper)." In: Irene Loutzaki (ed.): Proceedings. $17^{\text {th }}$ Symposium of the Study Group on Ethnochoreology. Dance and its Socio-Political Aspects: Dance and Costume (Nafplion, Greece: Peloponnesian Folklore Foundation/International Council for Traditional Music, 1994) 15-22, esp. 17.

8 About the wave of establishing professional state folk ensembles on the powerful example of the Soviet Igor Moiseyev's ensemble in Eastern Europe, the Middle East and Latin America and about the politicization of dance-stage and the claim of representing a nation in essentialist entirety in social and ethnic sense see Anthony Shay: "Parallel Traditions: State Folk Dance Ensembles and Folk Dance in 'The Field'”, Dance Research Journal, 31(1) (Spring, 1999): 29-56, University of Illinois Press.

9 What Anna Ilieva writes about the Bulgarian state-supported socialist official folk dance movement is reminiscent of the pre-dance house situation of folk-ensemble dancing in Hungary: "These groups were not formed as a leisure pastime but were demonstrative in character... Invented, artificial dances, which bore a faint resemblance to the rhythms, intonations, costumes and steps in original folklore, replaced Bulgarian ideas about the essence of folklore. From an integrated culture with a rich spirituality, the notion of folklore became associated with music with an untypical harmony and orchestral arrangement, and newly invented story and subject dances on a folk base which was a far cry from the original... Bulgarians could not sing a single song or dance a horo - they were helpless without a stage. The dancers were like cogs and wheels: screwed off the production, they were nothing." Anna Ilieva: "Bulgarian Folk Dance during the Socialist Era, 1944-1989”, Yearbook for Traditional Music 33 (2001): 123-126.

10 Ágnes Fülemile studied the process of disintegration of peasant culture in the period from World War I to the 1980s in 30 communities of Hungary in 1982-1988 under the tutelage of social anthropologist Edit Fél. Balázs Balogh carried out the fieldwork for his doctoral dissertation in the second part of the 1980s and first part of the 1990s. He studied farming and rural society in a Transdanubian community in 1920-1959. He furthermore did interviews with all 
the men of that generation who lived through collectivization as young adults and were forced to give up private farming.

11 See among others Tamás Hofer: "Construction of the 'Folk' Cultural Heritage in Hungary and the Rival Versions of National Identity", Ethnologia Europaea 21(2) (1991): 145-170.

12 Even at the moment characteristically extreme opinions for and against are burdened by many kinds of historical antecedents and previous political-ideological overtones, and numerous prejudices make assessments difficult. Today's creative folk artists carry on a valuable intellectual legacy and attention to folk culture has been continuous among a relatively wide audience, but the general image of folk culture is still characterized by superficiality. It appears that anyone can mock folk art, and advertisements and commercials appear in the media and in mass communication at its expense. On television one bank can make itself popular by telling the clients, who stare uncomprehending at people unexpectedly breaking into folk dance, that they aren't awaiting you with such surprises, but rather with good interest rates. A few years ago Budapest was full of advertising posters according to which "In life one must try everything, except for syphilis and folk dancing." A constant figure in theater and TV cabarets is the stupid fake peasant speaking a fake dialect. In Hungary the mass communication of the globalizing world is thus not indifferent to folk culture: it presents it as old junk to be tossed out, along with the outdated, obsolete peasant world. The presence in every field, alongside genuine creations of living folk art, of commercially more successful junk, which everyday people and tourists (and in many cases the various media as well) can barely distinguish (if at all), makes it difficult to advocate these values. In many cases even those who deal with culture or cultural management as a profession are unfamiliar with the prized assets of folk art. And in the conviction that whatever they are unfamiliar with must be worthless, they make no secret of their prejudices.

13 In fact the hydrocephalic role of the capital in every terrain of life was a historic consequence of the Trianon Peace Treaty in 1920, after which two-thirds of the territory of the country, including several large cities, was lost, leaving Budapest the only metropolis in the country. The uneven distribution of administrative, economic, cultural and educational institutions headed by the all-encompassing principle of centralization remained a real structural developmental problem of the whole country in the period of socialism.

14 Fradi (an unofficial abbreviation for the Ferencváros Athletic Club) represented the oppressed nationally-minded sports community against the teams favored by the regime, national defense (Budapesti Honvéd), the police (Újpesti Dózsa), labor (Vasas) and numerous rural mining communities (Tatabánya, Diósgyőr, Oroszlány, Komló, Ózd, etc.). To this day, although Fradi now plays only in the Hungarian second division, every sport-loving Hungarian from beyond the borders roots for Fradi. Émigré Hungarians who fled Hungary after 1945 always invited Fradi to tour Western Europe, South America and the United States. During the years of socialism many outstanding Hungarian football players were not permitted to sign with Fradi as an attempt to put the brakes on the team's popularity. While in Europe soccer attracts the biggest crowds, it has sunk to such a low level in Hungary since the mid-1980s that it has lost its fan base. It is primarily team sports that attract fans, but the still successful water polo and handball teams are incapable of moving masses like the Hungarian football that won the UEFA Cup in 1985 and beat the Brazilian national team 3-0 in 1986.

15 See chronology of events at this early phase in Ferenc Bodor: Nomád nemzedék - The Nomadic Generation (Budapest, 1981), László Maácz: "Folk Dancing and the Folk Dance Movement," in Edit Kaposi and Ernő Pesovár (eds.): The Art of Dance in Hungary (Budapest: Corvina, 1985), 57-65, 105-108; Sándor Striker: "The Dancehouse - Folklorism in Hungary in the 1970s," in Joseph Katus and János Tóth (eds.): Forum, vol. 1 (Papers from the Hungarian-Dutch Cultural Symposium) (Budapest: Institute of Culture; Leiden: Department of An- 
thropology, 1987), 100-131; Judit Frigyesi: "The Aesthetic of the Hungarian Revival Movement," in: Mark Slobin (ed.): Retuning Culture: Musical Changes in Central and Eastern Europe, Durham: Duke U. Press, 1996, 54-75; Béla Halmos: “The Táncház Movement." Hungarian Heritage 1(1-2) (2000), 29-40, 37-39; László Kürti: The Remote Borderland. Transylvania in the Hungarian Imagination (State University of New York Press 2001), Chapter: Youth and Political Action: The Dance House Movement and Transylvania 107-137.

16 See also Béla Halmos, ibid. 35-36 and Mary Taylor: "Institutional Precedents of the Hungarian Dance-House Movement”, in Fulbright Student Conference Papers (Budapest: Hungarian-American Commission for Educational Exchange, 2004), 95-103.

17 In 1961, with the first "Who knows what" (Ki mit tud?) show, Hungarian Television introduced a new genre of media entertainment: the talent contests, which gained immense popularity. Each year new contests were invented. In 1966 and 1967 the first and second Pop Song Festival (Táncdalfesztivál) legitimized the beat sound. Television needed singers in other genres as well. Encouraged by the popularity of the pop song contests, the first folk and popular art song contest was organized with the name Nyilik a rózsa (The Rose is Blooming) in 1968. The Röpülj páva (Fly Peacock) contest started in 1969. The competition lasted for a year and a half and had enormous influence. New voices (Laura Faragó, Kamilla Dévai-Nagy, Ilona Budai, Éva Ferencz) started their carriers with the Fly Peacock contest. Laura Faragó who won the Grand Prize, brought home a first prize from England a year later in 1971 from an International Folk Song Competition from Middlesbrough. In 1972, on the 90th anniversary of the birth of Zoltán Kodály, a singing competition was also organized that popularized the folk inspired art music of Kodály and Bartók and brought successes to classically trained opera singers. The 1973 Arany páva (Golden Peacock) contest was an international folk music competition in which instrumental musicians and bands were also competing along with the folk song singers. Further Fly Peacock contests were organized in 1977, 1981 and 1983. Counties competed in the 1977 Fly Peacock contest. In addition to the musical program, regions and villages of competitors were introduced by short ethnographic documentary reports. The main organizer and speaker of the program, choir leader Lajos Vass, himself helped organize many of the Fly Peacock circles, which were established in the countryside as a result of the popularity of the program.

The TV director of the Fly Peacock show, Miklós Lengyelfi, himself had a degree in ethnography.

18 Neil V. Rosenberg (ed.): Transforming Tradition: Folk Music Revivals Examined (Urbana: University of Illinois Press, 1993); Chris Goertzen: Fiddling for Norway: Revival and Identity (Chicago: University of Chicago Press, 1997); Guntis Smidchens: A Baltic Music: The Folklore Movement in Lithuania, Latvia and Estonia, 1968-1991. Ph.D. diss., Indiana University.

19 Owe Ronström writes about the parallel between the Swedish and Hungarian revival movement: "...the stress on improvisation became in a way a stress on self-determination and re-establishment of the individuals' roles in the large structures, in society at large... So, here's where ends meet: reproduction, copying, which in fact was what many did, became equated with passivity, taking orders from above, centralization, mass consumption. To improvise, or at least to try, became a way of taking command, acquiring power at least over yourself and your own actions. Thus dancing and music-making became a field where individuality could be developed and expressed, in a society which seemed to leave too little room for individual expressivity." Owe Ronström: "Revival in Retrospect. The Folk Music and Dance Revival". European Centre for Traditional Culture, Bulletin IV. Budapest 12-13/9, 5-6.

20 Béla Halmos, ibid., 29-40, 29.

21 Among the very first dance cycles in the dance house and the repertoire of dance-groups right from the very beginning there were Romanian, Serbian, Croatian, Bulgarian, Greek and then a 
bit later Slovak, Polish-Goral, Gypsy and Jewish music and dance as well. In addition to the so-called Hungarian dance houses, where the mix of styles appeared, there were separate Serbo-Croatian, Greek etc. dance houses that developed around music bands such as the Vuicsics band, which were absolute contemporaries of the first Hungarian music playing bands. In fact there was a great permeability among the visitors and musicians of the dance clubs.

22 Béla Halmos, ibid., 30.

23 See László Kürti: "Rocking the State: Youth and Rock Music Culture in Hungary, 1976-1990", East European Politics and Societies 5 (1991): 483-513.

24 The composer of the music and the author of the text, Levente Szörényi and János Bródy, were members of the bands Illés and later Fonográf, one of the most progressive and popular bands of the late $60 \mathrm{~s}$ and $70 \mathrm{~s}$.

25 In traditional balls and weddings dance-verses were shouted by the dancers to encourage or tease one another's dancing.

26 Interview with József Tornai by Zoltán Pósa, A zsurnalizmus kora olykor megdöbbent Beszélgetés a nyolcvanegy éves Tornai Józseffel. http://www.mno.hu/portal/538014? searchtext=A\%zsurnalizmus\%20kora

27 See the results of a survey by István Fábri and Katalin Füleki: “A táncház közönsége: szociológiai jellemzők, értékek, életmód," in A betonon is kinö a fü: Tanulmányok a táncházmozgalomról, ed. Ildikó Sándor (Budapest: Hagyományok Háza, 2006), 41-66. 